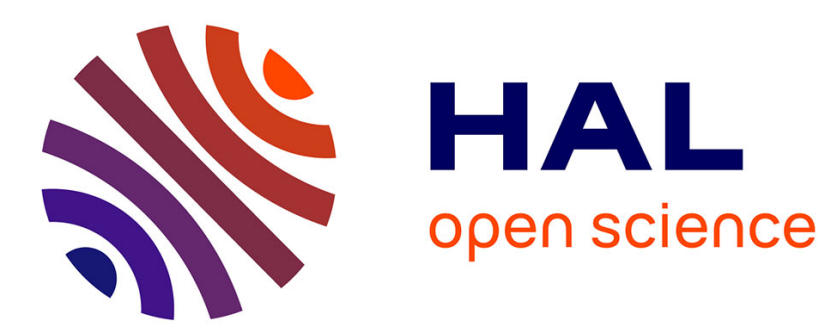

\title{
An analysis of science-industry collaborative patterns in a large European University
}

Rachel Levy, Pascale Roux, Sandrine Wolff

\section{To cite this version:}

Rachel Levy, Pascale Roux, Sandrine Wolff. An analysis of science-industry collaborative patterns in a large European University. Journal of Technology Transfer, 2005, 34 (1), pp.1-23. 10.1007/s10961007-9044-0 . hal-00279261

\section{HAL Id: hal-00279261 \\ https://hal.science/hal-00279261}

Submitted on 21 Feb 2022

HAL is a multi-disciplinary open access archive for the deposit and dissemination of scientific research documents, whether they are published or not. The documents may come from teaching and research institutions in France or abroad, or from public or private research centers.
L'archive ouverte pluridisciplinaire HAL, est destinée au dépôt et à la diffusion de documents scientifiques de niveau recherche, publiés ou non, émanant des établissements d'enseignement et de recherche français ou étrangers, des laboratoires publics ou privés. 


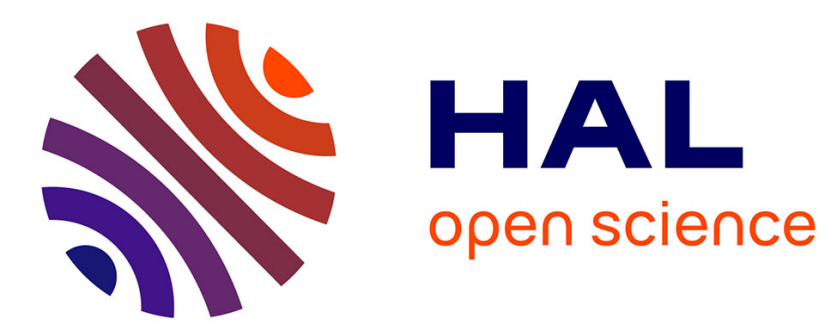

\title{
An analysis of science-industry collaborative patterns in a large European University
}

\author{
Rachel Levy, Pascale Roux, Sandrine Wolff
}

\section{To cite this version:}

Rachel Levy, Pascale Roux, Sandrine Wolff. An analysis of science-industry collaborative patterns in a large European University. Journal of Technology Transfer, Springer Verlag, 2005, 34 (1), pp.1-23. 10.1007/s10961-007-9044-0 . hal-00279261

\section{HAL Id: hal-00279261 \\ https://hal.archives-ouvertes.fr/hal-00279261}

Submitted on 21 Feb 2022

HAL is a multi-disciplinary open access archive for the deposit and dissemination of scientific research documents, whether they are published or not. The documents may come from teaching and research institutions in France or abroad, or from public or private research centers.
L'archive ouverte pluridisciplinaire HAL, est destinée au dépôt et à la diffusion de documents scientifiques de niveau recherche, publiés ou non, émanant des établissements d'enseignement et de recherche français ou étrangers, des laboratoires publics ou privés. 
See discussions, stats, and author profiles for this publication at: https://www.researchgate.net/publication/23693519

\section{An analysis of science-industry collaborative patterns in a large European University}

Article in The Journal of Technology Transfer · February 2006

Source: RePEc

CITATIONS

35

3 authors:

Rachel Levy

Toulouse 1 Capitole University

37 PUBLICATIONS 385 CITATIONS

SEE PROFILE

Sandrine Wolff

University of Strasbourg

36 PUBLICATIONS 1,190 CITATIONS

SEE PROFILE

Some of the authors of this publication are also working on these related projects:

Project Netscience View project
197

Pascale Roux

University of Bordeaux

41 PUBLICATIONS 569 CITATIONS

SEE PROFILE 

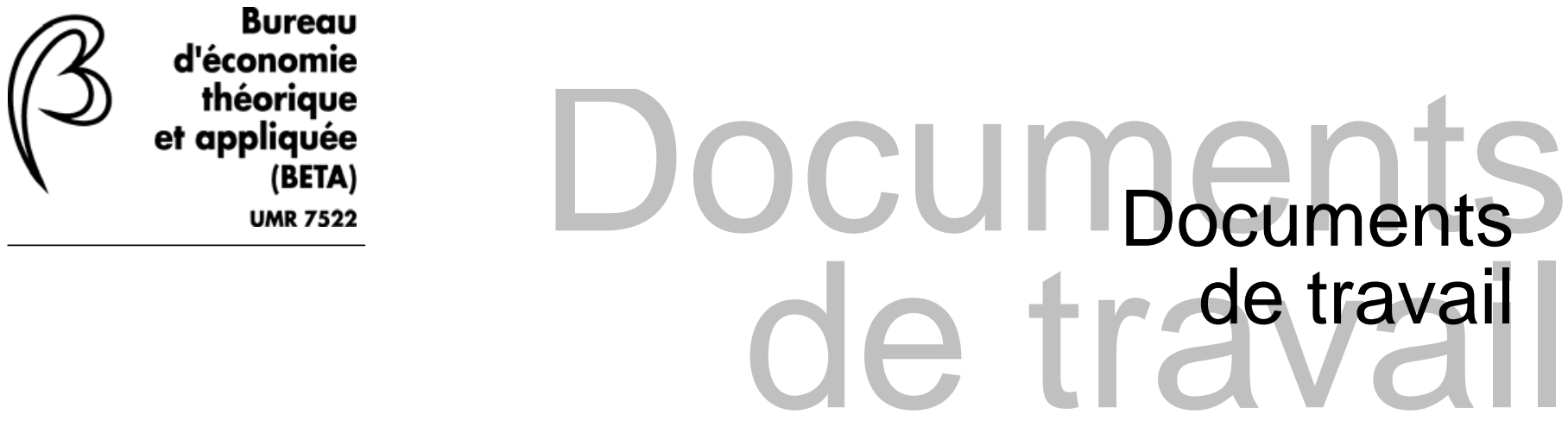

\title{
« An analysis of science-industry collaborative patterns in a large european university »
}

\author{
$\underline{\text { Auteurs }}$ \\ Rachel LEVY, Pascale ROUX, Sandrine WOLFF
}

Document de travail $\mathrm{n}^{\circ} \mathbf{2 0 0 6 - 2 7}$

Octobre 2006

Faculté des sciences économiques et de gestion

Pôle européen de gestion et d'économie (PEGE)

61 avenue de la Forêt Noire

F-67085 Strasbourg Cedex

Secrétariat du BETA

Christine Demange

Tél. : (33) 0390242069

Fax : (33) 0390242070 demange@cournot.u-strasbg.fr http://cournot.u-strasbg.fr/beta 


\title{
AN ANALYSIS OF SCIENCE-INDUSTRY COLLABORATIVE PATTERNS \\ IN A LARGE EUROPEAN UNIVERSITY
}

\author{
Rachel Levy (BETA, ULP, Strasbourg), \\ Pascale Roux (ADIS, Université Paris Sud \& BETA, ULP, Strasbourg) \\ Sandrine Wolff (BETA, ULP, Strasbourg) \\ (Corresponding author: levy@cournot.u-strasbg.fr )
}

October 2006

\begin{abstract}
.
This paper analyses the modalities according to which a large European university collaborates with firms by exploring its relational portfolio. We address this issue by exploiting a database listing more than 1000 firms having collaborated with the University Louis Pasteur between 1990 and 2002. First, using multi-correspondence analysis, we derive a four-classes typology of collaborative behaviours, each of them presenting a strong internal coherence. We obtain four distinct collaboration patterms, for which the frequency of interactions and the exclusive vs. open character of the relationships are discriminating features. Second, using a multinomial logit estimation, we show how this diversity is connected to some individual attributes of the firms: size, legal status, industrial sector and geographic distance from the public partner.
\end{abstract}

Keywords. Science-industry collaborations; Typology; Industrial collaboration patterns;

JEL Classification. L21; L31; O32

\footnotetext{
* This work is part of a larger project of a team of researchers at BETA co-ordinated by P. Llerena. We are grateful to all the members of this team. Acknowledgements should be extended to the administrative departments of ULP, the technology transfer offices of ULP and of local delegation of CNRS, and to the French patent office (INPI). The paper also benefited from the highly relevant and interresting comments of Natalia Zinovyeva, Maria Theresa Larsen and Réjean Landry.
} 


\section{Introduction}

Since the beginning of the 80 's, an intensification of the practices of collaboration between universities and firms has been observed, these collaborations taking very heterogenous forms and channels: purely informal exchanges of knowledge, co-publications, co-invention of patents, research contracts, researchers' mobility, etc. The phenomenon raised considerable scholars' attention (see for example Hall, Link \& Scott, 2000, Cohen et alii, 1998, Jankowski, 1999, Godin \& Gingras, 2000), probably because it conveys major policy implications in terms of innovation performance.

Indeed, the literature about university-industry collaborations is part of the broader set of mainly empirical - analysis concerning the relationships between Academia and the industrial sphere $^{1}$. Within a climate of rising questions concerning the economic relevance of scientific knowledge for Society (Gibbons et alii, 1994), some scholars have tried to assess and have found a positive impact of Science upon economic performance and/or firms' innovativeness (cf. Adams, 1990, Jaffe, 1989, Acs et alii, 1992). Other authors, on the ground of large surveys of firms and/or universities, have examined the role of Public research organizations (PROs), including universities, as a source of knowledge for innovating companies (Arundel \& Geuna, 2004, Klevorick et alii, 1995, Cohen, Nelson \& Walsh, 2002, Laursen \& Salter, 2004), leading to the idea that PROs are significant contributors to industrial innovations, although less important than suppliers or clients of the interviewed companies.

Beside this positive relationship from science to industry focussing on the transfer of scientific knowkedge to firms and its social benefit, the trend toward "commercialization of science" raises serious worry concerning possible damages on the norms of Open Science, as defined by Merton (1973) ${ }^{2}$. The collective organization of Science might thus suffer from restrictions in knowledge disclosure (less publications), as well as modifications in research agenda (oriented towards more applied research). Here again surveys, especially university surveys, provide interesting information about eventual changes in scientists' behaviors and opinions (see for instance Cohen et alii, 1998, Lee, 1998, Blumenthal et alii, 1997). While most of these empirical analysis tend to support the presence of information withholding

\footnotetext{
1 For a critical review about the benefits of public research, see Salter \& Martin (2001).

${ }^{2}$ See Dasgupta \& David (1994) for comprehensive theoretical developments about the New Economic of Science.
} 
behaviours, clear evidence concerning major changes in research agendas or decrease in research productivity seems to be absent. Thus the debate on the negative consequences of close links with industry upon Open Science efficiency remains open.

Studying the impact of Science upon economic performance and/or the reverse influence of industrial constraints upon university culture and efficiency fall well beyond the scope of the present paper, which rather aims at analysing the diversity of university-industry collaborations. But recallling these central issues of the literature is necessary to apprehend properly the strategic importance and the political implications of the collaborations between firms and universities. Among the broad set of science-industry linkages, the universityindustry collaborations present a distinctive property: they consist in two-ways exchanges of knowledge by contrast to unilateral transfers from university toward industry (MeyerKrahmer \& Schmoch, 1998). As such, they are privileged vehicles for interactive learning and innovation. However they potentially undergo higher risks of tensions and conflicts. Like Cassier (1997), we contend that they are better considered as loci of compromises and hybridization of the institutional rules governing public science and private research (respectively: disclosure and non appropriability versus secrecy and appropriability).

Whereas the motives, obstacles and impacts of university-industry collaborations are rather well documented through a growing number of empirical analysis based on firms' and/or universities' surveys, the great diversity of the forms of public/private collaborations still remains poorly analyzed. Exceptions are Cassier (1997), Joly \& Mangematin (1996), and Carayol (2003). However different cooperative modalities may well have different implications in terms of knowledge exchanges, innovation potential and cultural hybridization...How do companies cooperate with universities? Is it possible to identify different types of collaborative behaviours (or collaborative patterns)? If yes, do they correspond to specific firms' characteristics?

We attempt to address these questions by exploring the portfolio of industrial relationships of a large university. We base ourselves on a unique and original database about the research activity of a large, diversified and well-ranked European University : University Louis Pasteur (ULP) in Strasbourg, Widely acknowledged for its academic excellence, ULP covers almost all scientific fields (if we except Law, Art and Humanities), and has a strong and longstanding inclination toward fundamental resarch. The database gathers information about 
inputs and outputs of the university (human resources and laboratories, publications and patents) and about the research contracts with the private sector. The sample we use here comprises more than 1,000 firms having collaborated at least once with ULP between 1990 and 2002. In a first stage, a typology of collaborations patterns of ULP's industrial partners is derived, by the means of a multi-correspondence analysis followed by an ascendant hierarchical classification. We show that the frequency/variety of interactions on the one hand, and the number of participants (closed and dyadic relationship vs. open and multilateral partnership) on the other hand, are discriminating features of the various patterns we obtain. In a second stage of the analysis, we attempt to highlight this diversity according to the individual attributes of firms, using a multinomial logit estimation.

The paper is organized as follows. The next section introduces key concepts on scienceindustry collaborations based on existing literature. The third section provides information on the data and some descriptive statistics. The fourth section is dedicated to the typology of collaborative patterns (or profiles) of ULP's industrial partners. The fifth section presents the results of the econometric multinomial logit model, estimated on the basis of the classes to which the private partners belong. In the last section, we shall propose a synthesis of the results and some extensions for further research.

\section{Brief overview of the literature, main concepts and hypotheses}

\subsection{From a variety of interactions to diverse collaborative patterns}

Considering the notion of collaboration at the heart of the present contribution, it is necessary to define it more precisely before going any further into the analysis. If we accept the usual meaning of "collaborating", i.e. "working together in order to reach common goal(s)", it seems to us that talking about university-industry collaboration implies a clear move from a unilateral, knowledge sourcing perspective to a much more reciprocal, mutual exchange perspective, in order to reach the ultimate goal of creating new knowledge ${ }^{3}$.

A growing part of the literature about university-industry relationships highlights the diversity of the different channels of interaction linking PROs to companies, trying to compare their relative importance (see for instance Faulkner \& Senker, 1994, Cohen et alii, 1998, Cohen et

\footnotetext{
${ }^{3}$ Using an organizational learning perspective, Cyert \& Goodman (1997) provide very interesting insights and recommendations on the best way to create effective university-industry alliances.
} 
alii, 2002, Schartinger et alii, 2002, Meyer-Krahmer \& Schmoch, 1998, Arundel \& Geuna, 2004). It is worth mentioning here that the word "interactions" is a rather fuzzy concept that encompasses the mono-directional sourcing of scientific knowledge by companies (reading publications, surveying academic patents, hiring scientists,...) as well as more bi-directional knowledge exchanges like informal contacts, joint research contracts, co-publications and other forms of effective collaboration.

Like Meyer-Krahmer \& Schmoch (1998) we consider that effective collaborative relationships require bi-directional channels of interaction. It seems to us that mutual exchanges represent also a precondition for knowledge creation. And like Schartinger et alii (2002) we focus on interactions that suppose face to face contacts and a certain degree of formalisation. More precisely, among the different channels of interaction which are relevant for our purpose, we exploit information concerning (cf. section 3 for a detailed presentation of the data):

- co-authering of scientific articles by public and private researchers: here copublications are not considered as cooperative outputs, but rather as tangible signs of effective cooperation. More precisely co-authoring takes place at the level of individuals (not institutions) et usually requires informal inter-personal contacts.

- co-invention by private and public resarchers leading to a patent; like in the previous case, co-invented patents are mainly seen as codified, visible sign of - eventually more informal - collaboration;

- contractual arrangements between public research and industrial institutions, with a sharp distinction between "spontaneous", non publicly subsidized agreements ${ }^{4}$ (which we will call "private contracts" in the subsequent parts of this paper), and...

- $\quad$...E.U. sponsored agreements, that is to say subsidized collaborative projects signed in one of the Community's R\&D Framework Programmes.

The reason behind this distinction has to do with the hypothesis that E.U. agreements are somewhat less governed by secrecy rules and appropriability problems, inasmuch as they are multi-partners, obey to information disclosure rules ${ }^{5}$ and often concern pre-competitive

\footnotetext{
${ }^{4}$ Unfortunately our data do not make it possible to distinguish between contract reseach and joint research project.

${ }^{5}$ Information concerning the content, the objective and the partners of a given E.U. project is public information, available in the Cordis database. For a theoretical analysis concerning the distinciton between EU sponsored and private, spontaneous alliances, see Matt \& Wolff (2004).
} 
research $^{6}$. By contrast, "private contracts" are often dyadic (i.e. they involve only two partners; cf. also the notion of "bilateral" contract in the literature), which makes it possible to better preserve the confidentiality and the appropriability of the research outcomes (Cassier, 1997).

Of course we recognize that the four types of channels taken into consideration here are only a subset of the whole set of collaborative links. They were chosen because they represent measurable signals of formal but also informal forms of collaborations between universities and firms ${ }^{7}$. An additional, methodological aspect of our contribution deserves consideration : contrarily to most of the empirical analysis in the literature, we do not analyze the channels separately, but we explore their (possible) combinations.

In this paper our main goal is to address the diversity of university-industry collaboration practices. But we contend that a given collaboration project cannot be reduced to one given channel. A collaboration may well use several channels simultaneously. Comparing the relative importance of the individual channels might thus be misleading. Of course this statement is even more true if we consider a collaborative relationship as a whole, instead of a given project (a collaborative relationship covers a longer time horizon, taking all projects into account).

This is the reason why we use the four channels mentionned above as elementary bricks to build profiles of industrial partners. More precisely, we observe the type(s) of channels, their frequency and the way they combine for a given industrial partner of University Louis Pasteur. Then we used data analysis techniques to derive a typology of collaborative patterns, or, more precisely, a typology of collaborative profiles of ULP's private partners.

Focussing on the literature specifically devoted to science-industry alliances, it might be noted that very few authors adress explicitly the internal diversity of such strategies. Most analyses, probably because they use the data obtained through non dedicated (innovation) surveys, deal with university-industry collaborations as if the latter were belonging to a single and homogeneous category. Notable exceptions are Carayol (2003) and Joly \& Mangematin (1996).

\footnotetext{
${ }^{6}$ Caloguirou et alii (2001, in their analysis of university-industry cooperation in the context of European Framework Programmes, find that the number of partners in a project is higher in case of academic participation. They explain it by the characteristics of university research : basic/generic and less appropriable.

${ }^{7}$ This does not mean that we collected all informal collaborations. We missed the pure informal collaborations with no tangible co-output.
} 
By analysing qualitative data of 46 european collaborations in IT and Biotech/pharma, together with the main characteristics of both types of partners, the first author identifies five types of collaborations, depending on their degree of risk, novelty and basicness of research as well as on the number of partners (from bilateral research to networked research). Dealing with 182 research contracts of a large research organization (the French INRA, specialized in agronomy), Joly \& Mangematin were able to characterize 3 relational logics : (i) a proximity logic where collaborations aim at testing a given hypothesis to generate private benefits, are based on trust, imply exchange of tacit, specific knowledge and tend to lead to new contracts ; (ii) a club logic where collaborations aim at producing a technical referent interesting several firms (social benefit), do not require a lot of trust but the exchange of codified and standardized knowledge; (iii) a market logic where collaborations aim at gaining expertise to relieve a scientific bottleneck (private benefit), require reputation (not trust), imply the exchange of codified and specific knowledge and never lead to contract renewal.

The rest of the literature considers university-industry collaborations as a single category. It aims basically at explaining the propensity of particular firms to collaborate with universities (Fontana et alii, 2006, Mohnen \& Hoareau, 2003), the motivations for firms or universities to form public-private alliances (Caloghirou et alii, 2001, Lee, 2000, Miotti \& Sachwald, 2003, Saez et alii, 2002), or the obstacles and success factors of such collaborations (Hall et alii, 2000, 2001),

\subsection{Explaining the diversity of university-industry collaboration patterns: the role of sectoral membership, geographical proximity and size/status of the firm}

Keeping in mind that the present contribution explores the diversity - and provides a typology- of the collaboration profiles of the industrial partners of a big French university, an important question remains: what factors explain the diversity of observed collaborative profiles ? It is tempting to look for an answer (even though it is only a partial answer) in the specific, independant features of the partner companies themselves, for instance their size, status, activity, innovativeness,...

Although the literature about university-industry collaborations never raises the issue of wether the specific features of industrial partners (of a given university) explain the diverse collaborative patterns (linking them to that university), several papers analyse the firm's characterisitics that influence the propensity to cooperate with a PRO, thus providing useful indication about the characteristics that could be the most relevant for our purpose. To 
enumerate them briefly, these characteristics are : the size of the firm, its status (headquarter or subsidiary), its sectoral membership, its innovativeness (measured by the level of $R \& D$ expenditure), and its geographical proximity with university (location in the same region, country,...).

Trying to identify which types of companies have a greater propensity to cooperate with universities, Mohnen \& Hoareau (2003) find, among other characteristics, that companies collaborating in innovation with PROs have generally a big size (they also hold more patents, or are firms receiving government support to innovate). The result concerning the size is widely supported by recent empirical investigations about university-industry interactions (Cohen et alii, 2002, Arundel et Geuna, 2004, Laursen \& Salter, 2004, Fontana et alii, 2006) on the one hand, and about R\&D collaboration in general (Tether, 2002, Fritsch and Lukas, 2001), on the other hand. Nevertheless there is also some indication that start up have a higher probability to benefit from public research (Cohen et alii, 2002).

As far as the sectoral membership of companies having close links with university is concerned, the leading importance of hightech sectors and especially the biotechnology or pharmaceutical industry is often emphasized and rather well documented (Cohen et alii, 2002, Meyer-Krahmer \& Schmoch, 1998. See also Dalpé 2003 for an overview). Nevertheless, Schartinger et alii (2002), taking into account a wide range of university-industry linkages in the case of Austria, call into question the idea that the intensity of knowledge interaction follows a simple sectoral pattern (like: "hightech sectors having a high level of interactions versus lowtech sectors having weak interactions). It seems that sectoral patterns of interactions are much more complex than is commonly admitted.

Turning now to the geographical proximity factor and its influence on university-industry relationships, the results seem to vary considerably across empirical studies. Nevertheless, following Arundel \& Geuna (2004) or Mansfield \& Lee (1996) it might be suggested that geographical distance matters, especially at the national level. It can also be noted that, according to the former, this domestic preference does not hold for pharmaceuticals.

To what extent do the partners of our French University fit the picture that we have just described above? The next part of the paper sketches a - rough - answer to this question and more generally describes our data and variables. 


\section{Data and variables}

\subsection{The data}

The university under analysis is the University Louis Pasteur (ULP), a French scientific university based in Strasbourg (Alsace region in the North East of France). This university is internationally acknowledged for its academic excellence, and was in 2005 one of the four French universities ranked in the top 100 of the most performing universities in the world (ranking of the University of Shanghai ${ }^{8}$ ). On average this university trains about 18000 students and employs about 1500 researchers grouped in more than 70 units of research in mathematics, physics, chemistry, earth and universe sciences, engineering sciences and social sciences $^{9}$. Nevertheless, ULP is widely acknowledged for its specialization in chemistry and life sciences.

In our analysis of the private partners of this university, we use a large database (more accurately a set of several databases) about the characteristics of public research at ULP. This database gives an account of the university's composition and its scientific activities. It gathers information about inputs of the search process (human resources of the university), (such as publications and patents) and about its research contracts with the private sector ("private" contracts and E.U. sponsored research contracts). More precisely information is organized and centralized on the ground of the list of the 1805 permanent researchers and 105 research units of the university. These two databases come from information contained in official documents, produced by each ULP's lab in the specific, French context of four-year contractual affiliation rounds (“contrats quadriennaux") ${ }^{10}$.

Concerning the outputs of research, we collected information about all the publications cited in the Science Citation Index or Social Science Citation Index (bibliographic databases produced by ISI), published between 1990 and 2002 by at least one researcher mentionned in the "permanent researchers' database" ${ }^{11}$. In parallel, we identified all the 841 patents (French, European or American) invented by at least one researcher mentionned in the same database. We completed the data by collecting all the 4495 research contracts signed, between 1990 and 2002, by one of the ULP's laboratories, thanks to the technology transfer offices of the university (ULP-industry) and of the CNRS. This “contract database” provides a few

\footnotetext{
${ }^{8} \mathrm{ULP}$ was class as the $92^{\text {nd }}$ rank : http://ed.sjtu.edu.cn/ranking.htm

${ }^{9}$ The half of theses units of research are associated to the CNRS.

${ }^{10}$ Each lab produces a document summarizing its research activity and its composition for the last four years, as well as a forecast of its research activity for the four next years.

${ }^{11}$ We have collect 43241publications which correspond to 23215 different article if we deleted the article publish by different ULP researchers.
} 
information about the contracts themselves, the name of the different partners (firms and public institutions), including the contracts executed in the frame of European Programmes.

Finally, the last step was the building of the list of the private partners of the university. To achieve this, we considered the industrial partners that had collaborated with ULP through a "private" (in the sense of non-subsidized) research contract, a European contract, a copublication and/or the ownership of a patent invented by a researcher of the university. This process resulted in a list of 1151 firms. For each firm we search for complementary information in the Dun \& Bradstreet Who Owns Whom database, more precisely: the company's geographic location, its sector of activity, its size and its ownership status (independent vs. subsidiary). We finally remove from our analysis 131 firms, for which we missed information either on the location, on the industry or the size/ownership status .

To summarize, the empirical analysis presented here is based on a list of 1020 firms which have collaborated with ULP between 1990 and 2002 through (at least) one of the following channels: a "private" (non subsidized) research contract, a E.U. contract, a co-publication and/or a co-invention leading to a patent. Before coming to the different channels of collaborations which link ULP to these firms, it interesting to give a quick overview of the characteristics and attributes of the latter, in terms of location, sector, and size/status.

\subsection{The variables}

Seven different variables have been taken into account in our study of the collaborations between ULP and its private partners. These variables can be gathered in two groups: the different types of collaborative channels (or links) and the degree of exclusiveness of the relationship. In the first group, each variable concerns a given type of collaborative channel:

- CONTRACTS: number of "private" research contracts signed between the private partner and any research unit of ULP between 1988 and 2002. In fact, as be explained further, this "number" can take 3 modalities: zero, one and more than one.

- EUR_CONTRACTS: number of contracts realized in the framework of a European research programme, involving the private partner and a research unit of ULP between 1988 and 2002.

- PUBLI: number of publications co-authored by a member of the firm and a researcher of ULP (employed by ULP between 1996 and 2000), with a publication date between 1992 and 2002. It can be noted that a publication written by two or more researchers of the university is counted only once in our analysis. 
- PATENT: number of patents owned by the firm between 1984 and 2001, and invented by at least one ULP researcher. As for the publications, a patent co-invented by two or more researchers of the university is counted only once in our analysis.

As explained in the precedent paragraphs, we considered patents and publications as a signal of a link between ULP and firms and not only as an output of a precedent research contract. To confirm this hypothesis, we could observe in the following table that only 47 firms (5\%) have owned a minimum of one patent and have participated to a research contract (including European contract). We could also note that 302 (29\%) firms have published a minimum of one article without participating to a research contract (including European contract).

Table 1. : Number of firms having patent or publication and contract or European research contract

\begin{tabular}{|c|c|c|c|c|c|c|c|c|c|c|}
\hline & \multicolumn{5}{|c|}{ Patent } & \multicolumn{5}{|c|}{ Publications } \\
\hline \multirow[t]{5}{*}{ Contract } & Contract/patent & 0 & 1 & $>1$ & total & Contract/publi & 0 & 1 & $>1$ & total \\
\hline & 0 & 470 & 241 & 226 & 937 & 0 & 193 & 225 & 183 & 601 \\
\hline & 1 & 20 & & 11 & 31 & 1 & 200 & 15 & 29 & 244 \\
\hline & $>1$ & 19 & 7 & 26 & 52 & $>1$ & 116 & 8 & 51 & 175 \\
\hline & total & 509 & 248 & 263 & 1020 & total & 509 & 248 & 263 & 1020 \\
\hline \multirow{5}{*}{$\begin{array}{l}\text { European } \\
\text { contracts }\end{array}$} & eur/patent & 0 & 1 & $>1$ & total & eur/publi & 0 & 1 & $>1$ & total \\
\hline & 0 & 752 & 129 & 56 & 937 & 0 & 433 & 120 & 48 & 601 \\
\hline & 1 & 29 & & 2 & 31 & 1 & 239 & 5 & & 244 \\
\hline & $>1$ & 51 & 1 & & 52 & $>1$ & 160 & 5 & 10 & 175 \\
\hline & total & 832 & 130 & 58 & 1020 & total & 832 & 130 & 58 & 1020 \\
\hline
\end{tabular}

The second group of variables does not correspond to specific types of links between the firms and the university, but it concerns any type of link with a given partner. Based on the number and on the nature of participants in a collaborative link, the variables are designed to apprehend the degree of exclusiveness (vs. openness) of the relationships between ULP and a given partner. The basic idea is to distinguish dyadic relationships from those including other universities or industrials. To build this set of variables we procede in two steps.

First, each link, whatever its type (contract, co-patent or co-publications) is defined as dyadic if only ULP and the private partner considered are involved. A dyadic link vehicles a high level of exclusiveness. In the case of non dyadic link, the link is further characterized as "industrial" if (at least) another private partner is included in the collaboration (in addition to the reference partner); otherwise the link is named "university". Thus "University" means that there is no other industrial partner, but that there is (at least) another university who collaborates with ULP and the reference private partner. An "industrial" link (as defined 
above) conveys a very high level of openness (it requires tolerance for a potential competitor), whereas a "university" link conveys an intermediary level of openness.

In a second step, we count the number of dyadic, industrial or university links for each industrial partner, and we obtain the three following complementary variables:

- DYADIC: number of links (contracts including European contracts, publications or patents) which concern exclusively ULP and the private partner.

- INDUSTRIAL: number of links which concern at least a second private partner (in addition to the university and the reference firm).

- UNIVERSITY: number of links concerning at least another academic partner, and no other private partner (in addition to the university and the reference firm).

After this presentation of the different variables taken into account in the analysis, we still have to explain the way of counting them. Indeed, if we want to analyse the differences in collaboration practices, it makes no sense to compare the accurate number of patents owned by a private partner with the number of contracts or the number of publications. For this reason, and also for technical reasons (namely: assuring good conditions concerning the initial population for implementing multiple correspondence analysis), it was decided to dichotomize each variable according to 3 modalities: zero links, only one link and more than one link. Indeed in Table 2 we can note that there is a rather well balanced repartition of each variable in these three modalities.

\subsection{Descriptive statistics}

We have also represented in table 2, the different variables relative to the characteristics of the firms: localization, sector of activity and size. In order to complete the description of these characteristics, we have computed in table 3, the correlation between the variable of link between the firms and ULP (contract, European contract, patent and publications) and these variables relative to the general characteristics of the firms (sector of activity, localization, and size).

As showed in the second half of Table 2, the majority of the partners of ULP are French private firms, often located in the central region around Paris $(22 \%$ of the total number of partners) and less in the Alsace region (15\%). We find also foreign companies (i.e. located abroad), in majority German (10\%) or American (12\%). To complete this description we could not in the table 3, that Alsatian and French firms are more used to participated to 
research contract than to European research contracts or publications. At the opposite, international firm are used (by definition of this modality of collaboration) to be included in European research contract, but also to have activity of patenting and publishing.

We can also observe in Table 1 that ULP researchers collaborate mainly with firms specialized in the pharmaceutical industry (32\% of the total number of partner) and in the chemical one (19\% of the total number of partner). In these two sectors of activities (and more particularly in the case of pharmacy), firms have tendency to patent and publish and not to make some contracts (even European contracts). Concerning the others sectors of activity, we could note in table 3, that for all the others sectors, firms are used to participate only punctually to research contract activities and not used to patent or publish.

Concerning the size of theses firms, we distinguish the subsidiaries of large groups (more than 10000 employees), the subsidiaries of small groups (less than 10000 employees) the independent firms (from less than 50 to more than 10000 employees). More than half of ULP's partners are subsidiaries of small and large industrial groups. Concerning the link between the size of the firms and their links with ULP, we could note that the practice of patenting and made European contract seems not link with the size of the firm. Concerning the participation to research contract we could note that small firm (independent $>50$ employees) are more used to make (punctual) research contract than bigger ones (independent 500-10 000) and reciprocally they are not used to patent and publish.

So we have seen in the precedent paragraph, that some characteristics of the firms are links to form of links with ULP. In order to complete this first descriptive analysis, we will try, in the following paragraph to determine some pattern of collaboration of the firms with ULP and after to link these patterns of collaboration with the characteristics of the firms. 
Table 2. Presentation of the variables

\begin{tabular}{|c|c|c|c|c|}
\hline & Variable & Modality & $\begin{array}{l}\text { Number } \\
\text { of firms }\end{array}$ & $\%$ \\
\hline EUR_CON1 & TRACTS : & Eur0 : 0 contracts & 832 & $81,6 \%$ \\
\hline Number of $\mathrm{c}$ & contracts realized in the & Eur1 : 1 contract & 130 & $12,7 \%$ \\
\hline frame of Eur & ropean programmes & Eurmore 1 : more than 1 contract & 58 & $5,7 \%$ \\
\hline CONTRACI & TS : & Contract $0: 0$ contract & 509 & $49,9 \%$ \\
\hline Number of $r$ & research contracts & Contract1: 1 contract & 248 & $24,3 \%$ \\
\hline (excepting E & European contracts) & Contractmore $1::$ more than 1 contract & 263 & $25,8 \%$ \\
\hline PATENT: & & Patent0 : 0 patent & 937 & $91,9 \%$ \\
\hline Number of $\mathrm{p}$ & patents owned by the & Patent1 : 1patent & 31 & $3,0 \%$ \\
\hline $\begin{array}{l}\text { firm and inv } \\
\text { researcher of }\end{array}$ & $\begin{array}{l}\text { ented by at least one } \\
\text { f ULP }\end{array}$ & Patentmore 1 : more than 1 patent & 52 & $5,1 \%$ \\
\hline PUBLI : & & Publi0 : 0 publication & 601 & $58,9 \%$ \\
\hline $\begin{array}{l}\text { Number of } \mathrm{p} \\
\text { by a firm's } \mathrm{m}\end{array}$ & $\begin{array}{l}\text { publications coauthored } \\
\text { nember and at least one }\end{array}$ & Publi1 : 1 publication & 244 & $23,9 \%$ \\
\hline researcher of & f ULP & Publimore1: more than 1 publication & 175 & $17,2 \%$ \\
\hline DYADIC: & & Dya0 : 0 link & 342 & $33,5 \%$ \\
\hline Number of li & inks concerning only & Dya1 :1 link & 303 & $29,7 \%$ \\
\hline ULP and the & firm & Dyamore 1 : more than 1 link & 375 & $36,8 \%$ \\
\hline INDUSTRI & AL: & Indus0 : 0 link & 717 & $70,3 \%$ \\
\hline Number of li & inks concerning at least & Indus1:1 link & 207 & $20,3 \%$ \\
\hline one second $\mathrm{p}$ & private partner & Indusmore 1 : more than 1 link & 96 & $9,4 \%$ \\
\hline UNIVERSI & TY: & Univ0 : 0 link & 758 & $74,3 \%$ \\
\hline Number of li & inks concerning at least & Univ1:1 link & 181 & $17,7 \%$ \\
\hline $\begin{array}{l}\text { one other ac } \\
\text { other industr }\end{array}$ & $\begin{array}{l}\text { ademic partner, and no } \\
\text { rial }\end{array}$ & Univmore1: more than 1 link & 81 & $7,9 \%$ \\
\hline & Alsace & Alsace & 116 & $11,4 \%$ \\
\hline & & Ile-de-France & 221 & $21,7 \%$ \\
\hline & France & Rhone-Alps & 47 & $4,6 \%$ \\
\hline Geographic & & Other French regions & 148 & $14,5 \%$ \\
\hline location & & Germany & 101 & $9,9 \%$ \\
\hline & International & Other country of Europe & 177 & $17,4 \%$ \\
\hline & internauonat & United-States & 121 & $11,9 \%$ \\
\hline & & Other countries & 89 & $8,7 \%$ \\
\hline & Pharmacy & Pharmacy & 323 & $31,7 \%$ \\
\hline & Chemical industrial & Chemical industrial & 197 & $19,3 \%$ \\
\hline & Mechanical equipment & Mechanical equipment & 87 & $8,5 \%$ \\
\hline & Instrumentation/IT & Instrumentation and precision equipment & 73 & $7,2 \%$ \\
\hline & instrumentauon/11 & Electronics, computer & 73 & $7,2 \%$ \\
\hline Sector or & & Traditional industry & 31 & $3,0 \%$ \\
\hline & Traditional industry & Metallurgy & 30 & $2,9 \%$ \\
\hline & & Food industry & 38 & $3,7 \%$ \\
\hline & & Services & 47 & $4,6 \%$ \\
\hline & Networks and services & Technical service and software & 84 & $8,2 \%$ \\
\hline & & Network services (telecom, energy, transportation ) & 37 & $3,6 \%$ \\
\hline & Indpt $<50$ & Small independent firm (<50 employees) & 201 & $19,7 \%$ \\
\hline & Indpt 50-500 & Independent firm (50-500 employees) & 123 & $12,1 \%$ \\
\hline Size and & Indpt 500-10000 & Independent firm (500-10000 employees) & 92 & $9,0 \%$ \\
\hline status & Indpt $>10000$ & Large group (independent firm > 10000 employees) & 85 & $8,3 \%$ \\
\hline & Ssg & Subsidiaries of small groups (group < 10000 employees) & 174 & $17,1 \%$ \\
\hline & Slg & Subsidiaries of large groups (group > 10000 employees) & 345 & $33,8 \%$ \\
\hline
\end{tabular}


Table 3. Correlation between the variable of link and the characteristics of the firms

\begin{tabular}{|c|c|c|c|c|c|c|c|c|}
\hline & Eur1 & Eurmore1 & Contract1 & Contractmore1 & Patent1 & Patentmore1 & Publi1 & Publimore1 \\
\hline Pharmacy & -0.12110 & -0.09430 & -0.11560 & 0.02750 & 0.06360 & 0.07220 & 0.14690 & 0.18770 \\
\hline Chemical ind. & -0.04240 & -0.09050 & -0.15030 & 0.07200 & -0.00360 & 0.05280 & 0.08200 & 0.10910 \\
\hline $\begin{array}{l}\text { Mechanical } \\
\text { equipment }\end{array}$ & 0.08330 & 0.07660 & 0.04780 & -0.05960 & 0.02770 & 0.00900 & -0.07250 & -0.12030 \\
\hline $\begin{array}{l}\text { Instrumentation } \\
\text { /IT }\end{array}$ & 0.09560 & 0.12930 & 0.00330 & -0.05530 & -0.03970 & -0.06930 & -0.02580 & -0.03750 \\
\hline Traditional ind. & -0.03590 & -0.03760 & 0.11530 & 0.07170 & -0.00020 & -0.04590 & -0.09850 & -0.07010 \\
\hline $\begin{array}{l}\text { Networks and } \\
\text { services }\end{array}$ & 0.02050 & 0.01650 & 0.09950 & -0.05630 & -0.04780 & -0.01880 & -0.03210 & -0.06890 \\
\hline Alsace & -0.1 & & & & 0.04450 & & -0.10680 & -0.00740 \\
\hline France & -0.21410 & -0.11670 & 0.15980 & 0.21110 & 0.02810 & 0.08980 & -0.11250 & -0.01600 \\
\hline international & 0.34170 & 0.19130 & -0.25190 & -0.39530 & -0.07260 & -0.13310 & 0.21930 & 0.02340 \\
\hline Indpte $<50$ & 0.01970 & -0.09650 & 0.17950 & 0.05780 & -0.04510 & -0.01300 & -0.13610 & -0.09370 \\
\hline Indpt 50-500 & 0.03900 & -0.01290 & 0.04280 & -0.06000 & -0.01290 & -0.03110 & 0.00410 & -0.05670 \\
\hline $\begin{array}{l}\text { Indpt 500- } \\
10000\end{array}$ & -0.02800 & 0.05570 & -0.06680 & -0.06820 & 0.08380 & -0.01070 & 0.07210 & 0.02010 \\
\hline Indpt $>10000$ & 0.01240 & 20 & -0.09650 & -0. & 0.00860 & 0.0 & 0.09700 & 0.05100 \\
\hline Ssg & -0.04950 & 450 & -0.10570 & & -0.03000 & & 0.02170 & 0.14740 \\
\hline Slg & 0.00640 & 0.03500 & 0.04670 & 0.01870 & -0.00440 & -0.04590 & -0.05880 & -0.06810 \\
\hline
\end{tabular}

\section{Collaboration patterns between ULP and its private partners: A typology}

\subsection{Methodology}

To study the collaboration profiles of the private partners of ULP, we have performed a Multiple Correspondence Analysis (MCA) on the collaboration variables defined above, followed by an ascendant hierarchical classification (AHC). This methodology is well adapted for qualitative data, since our aim is to explore the diversity of ULP relations whereas a structural model would tend to emphasize the main trends.

First of all, the MCA is designed to analyze the relations between more than two categorical variables that can be presented in multi-way contingency tables. It allows us to identify the relationships between the variables retained for the analysis. More precisely, the total variation of the data matrix (the inertia) is computed by the usual $\mathrm{Chi}^{2}$-statistics which measures the distance separating the original distribution from the one assuring the independence of the variables. Three main criteria can be used to retain the more discriminating axes of the analysis: the percentage of the inertia explained; the marginal contribution of the axes to the inertia explained; and the general meaning of the axis which will constitute the new synthetic variables (Benzécri, 1992). Since the more the number of axes retained for the AHC the more variance intra-class of the resulting classes, researchers often only keep two or three axes. 
In a second stage, the individuals' co-ordinates on the selected axes are the inputs for the AHC, which is used to partition the population into homogeneous groups. The AHC algorithm proceeds as follows: at each step pairs are formed by merging the closest clusters in order to minimize the within-types variance and to maximize the between-types one. The comparison of these two values (intra vs. inter-class variances) is the criterion used for choosing the number of classes to be retained. Finally, in order to highlight the main characteristics of the individuals by class, the co-ordinates of the classes' centers are represented on the axes determined in the MCA.

The variables used for the typology are the following: the types of collaborative link ("number" of non EU contracts, of EU contracts, of co-publications and of co-invented patents), and the exclusiveness of the relationships between ULP and its partners ("number" of dyads, number of links involving another firm, number of links invoving another university and no other firm). The specific attributes of the partners (sector, size, status and location) are used in the third and last stage of our study (cf. section 5.). It will consist in a multinomial logit regression. The aim will be then to capture some micro-foundations of our typology.

\subsection{Results}

Following the MCA, two axes are retained that explain 36\% of the total inertia of the data, which is a good ratio (the first axis explains $19.5 \%$ and the second, $16.5 \%$ of this inertia) $)^{12}$. The co-ordinates of the individuals (private partners of ULP) of the sample on these axes enabled us to carry out an AHC which results in a partition of the population into four homogeneous classes, with an intra-class variance of $19.4 \%$ and an inter-class variance of 80.6\%. This indicates a very good homogeneity of the firms inside each class. Thus these classes gather firms with similar profiles as regards the variables retained for the analysis ${ }^{13}$. The projection of the centers of these classes on the two factorial axes shows that the first axis strongly opposes Class 2 to Classes 1 and 4, whereas the second axis opposes Class 1 to Classes 4 and even more 3.

\footnotetext{
${ }^{12}$ For instance, Carayol and Matt retained four axes that explain 39\% of the total inertia of the data

${ }^{13}$ We have decided to form four classes of firms, because in the case of 3 classes the intra-class variance was equal to 31.8 and the inter-class variance was equal to 68.2. And in the case of five class, the variance intra-class was equal to 11.9 and the variable inter-class of 88.1, but in this case, we only separate the smallest class of 105 firms in two groups of 32 and 73 firms.
} 
As Figure 1 shows, the first axis can be interpreted as opposing private partners with dyadic collaborative behaviors to those which on the contrary collaborate with several other organizations (industrial or universities) more particularly in the form of European contracts. The second axis is related to the frequency and variety of interactions with ULP. Two main types of private partners can be distinguished: those which collaborate only punctually (just one collaboration) to those which collaborate more regularly with the ULP. In this latter case, collaborations often include repeated co-inventions of patents or co-publications.

The results point the diversity of the collaborations strategies of ULP partners. We describe successively the four classes obtained according to their position on the two first axes of the MCA $^{14}$. We also present for each class, their general characteristics (localization, sector of activity and size) summarized in Table 2. Nevertheless, we will not precisely detail these general characteristics since they will be reconsidered in the second stage of our study.

Figure 1. The projection of the classes' centers and the variables contributing to the first and second axes of the MCA.

\footnotetext{
${ }^{14}$ All the indications which are to be given below and which relate to the form of the collaborations (bilateral vs. multilateral, patents, publications, contracts ...) only concern firms relations with ULP.
} 


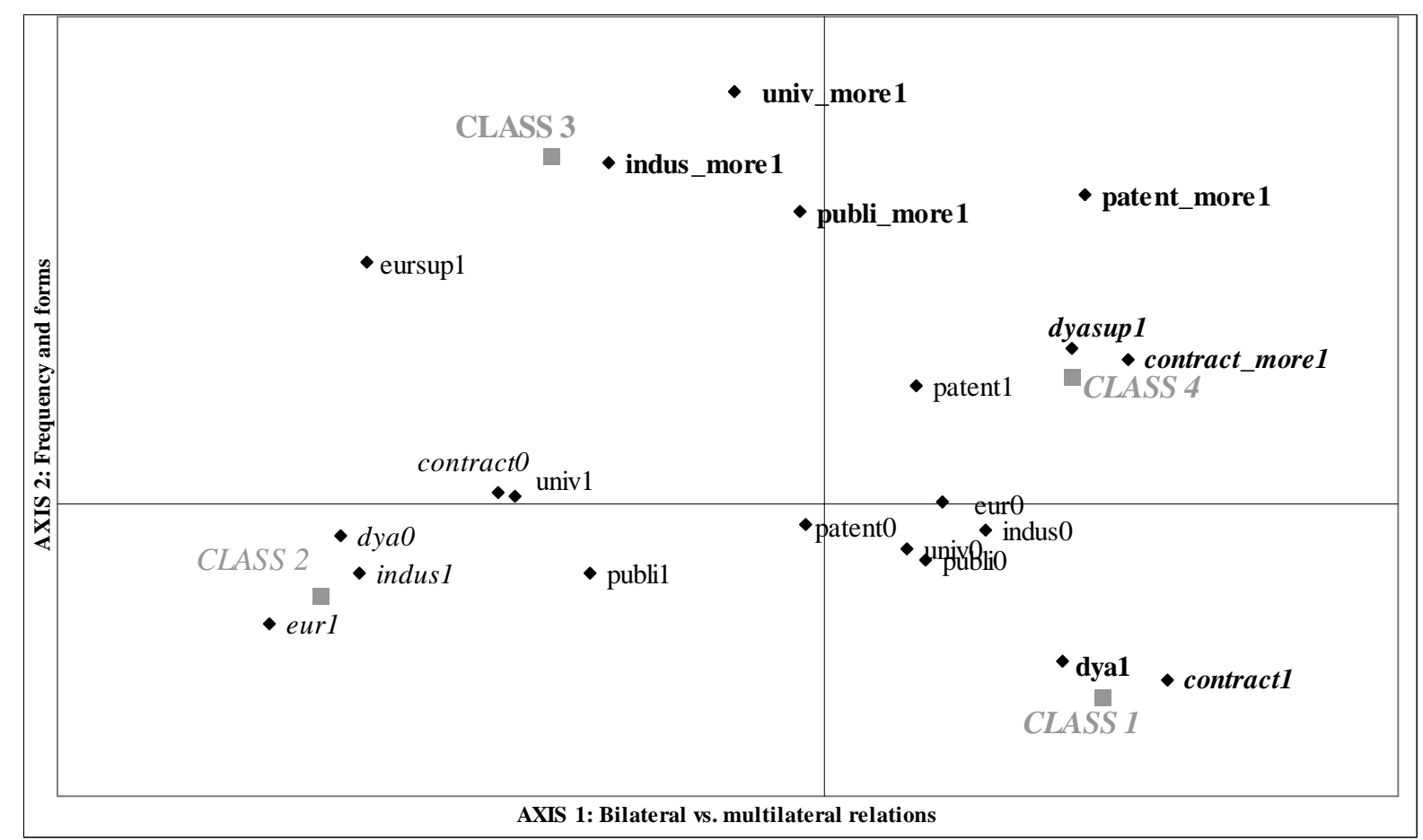

NB: The variables indicated in italic type contribute to the horizontal axis (factor 1) and the variables in bold contribute to the vertical one (Factor 2). The abbreviations used are presented in Table 1.

Figure 2. Number of firms by class

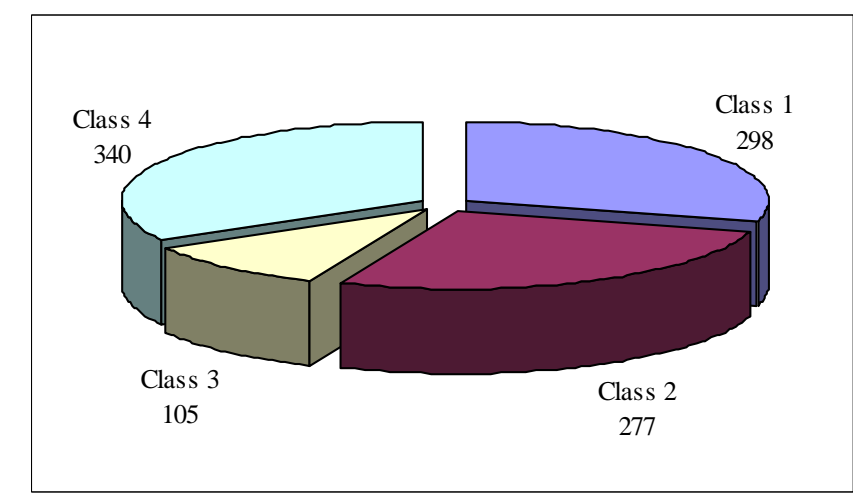

Source: Authors' calculation based on ULP partners database.

Class 1 gathers 29\% of ULP partners which maintain punctual and dyadic relations with this university. In fact these companies collaborate punctually with ULP and mainly in the form of contracts. Thus, $78 \%$ of these firms collaborate through the achievement of one contract (not European) and in a bilateral way with a research unit of ULP (90\% of these partners collaborate in a dyadic way with ULP). Few of them take part in publication activities (23\% of the companies of this class have only one scientific publication and none 
more than one, with ULP) and even less in patent activities (only 3\% of them apply for only one patent and none of them for more than one). As we can see in Table 2, the private partners of Class 1 are not specialized in a given sector. Moreover, these firms are localized in Alsace, France and in the rest of the world in similar proportions as the global population of partners. Finally, they do not maintain long term relations with the ULP and it seems that they seek to punctually benefit from ULP’s expertise in a specific domain.

Class 2 gathers 27\% of ULP partners which maintain punctual and multipartner relations with this university. In fact, these companies collaborate also punctually with the ULP, but rather through European contracts (in partnership with several companies and/or several universities). About half of these companies take part in European contracts (45\% of the class). Contrary to the firms of the first class, they do not achieve research contracts (this is the case for $99 \%$ of the firms of the Class 2). But in the same manner as the firms of the first class, the private partners which collaborate rather punctually with the ULP do not take part in patent activities (98\% of them never applied for a patent in collaboration with the ULP). Nevertheless, they are often engaged in publications activities. As Table 4 below shows, Class 2 gathers actually two subclasses: the partners which take part in European contracts (42,3\%) vs. those which collaborate with the ULP through one publication (53\% of them).

Table 4. Publications and European contracts in Class2

\begin{tabular}{lrrrr} 
& Publi0 & Publi1 & Publimore1 & Total \\
\hline Eur0 & 5 & 136 & 11 & 152 \\
Eur1 & 112 & 5 & 1 & 118 \\
Eurmore1 & 7 & 0 & 0 & 7 \\
\hline Total & 124 & 141 & 12 & 277 \\
\hline
\end{tabular}

In both cases, the collaboration is punctual but, in opposition to Class 1, these relations are multilateral since they are carried out with another private partner (60\% of Class 2), or another university (45\% of Class 2). They are more than average specialized in the sector of pharmacy, international companies, and rather subsidiaries of large groups.

Class 3 is the smallest class since it gathers only $10 \%$ of our sample of firms. It concerns firms which maintain regular, multipartner and multiform relations with ULP. These partners are characterized by both a strong intensity of collaboration (they have often more than one link with the ULP) and by a large variety of their relations with the university. In other words, they collaborate very regularly with ULP and in various forms: research contracts (16\% achieved more than one contract), European contracts (45\% took part in more than one 
European contract) and in the form of multilateral relations. Moreover, their degree of openness is much higher than average : 70\% have more than one link including at least another private partner. This result is highly compatible with a weak degree of exclusiveness (61\% of Class 3 companies have no dyadic link, to be compared to the $33 \%$ of the whole population). It is worth noting also that these collaborations include, in the majority of the cases, some copublications (62\% of them) and/or patent co-inventions (16\% applied for one or more patents). In 13 cases, the activities of publication and patenting are simultaneously achieved, indicating that both activites are not incompatible and might be complementary ${ }^{15}$. In terms of size and sector of activity, the firms of this class are more than average international companies distributed in various sectors of activity. Indeed, it should be noticed that there are very few firms originated from the Alsace region in this class (only five). By the means of a deeper inquiry, one can add that except for seven partners (including the five Alsatian firms), the firms of this class collaborate with several ULP research labs ${ }^{16}$.

\footnotetext{
${ }^{15}$ This result is highlighted by Carayol et Matt (2004) in the case of the more productive research labs of ULP.

${ }^{16}$ It can be mentioned that Alsatian firms have privileged relations with only one research lab or even with one or two academic researchers of ULP. In the same time, they have intense publications activities with them (more than one publication for each of them).
} 
Table 5. Description of the classes

\begin{tabular}{|c|c|c|c|c|c|c|c|}
\hline & By class (in \%) & & CLS_1 & CLS_2 & CLS_3 & CLS_4 & Total \\
\hline \multirow{21}{*}{$\begin{array}{l}\text { VARIABLES } \\
\text { OF THE } \\
\text { TYPOLOGY }\end{array}$} & \multirow{3}{*}{ European contracts } & Eur0 & 98,7 & $\overline{54,9}$ & 50,5 & $\overline{97,9}$ & $\overline{81,6}$ \\
\hline & & Eur1 & 1,3 & 42,6 & 3,8 & 1,2 & 12,7 \\
\hline & & Eurmore1 & 0 & 2,5 & 45,7 & 0,9 & 5,7 \\
\hline & \multirow[t]{3}{*}{ Contracts } & Contract0 & 21,5 & 99,6 & 82,9 & 24,1 & 49,9 \\
\hline & & Contract1 & 78,5 & 0 & 1,0 & 3,8 & 24,3 \\
\hline & & Contractmore1 & 0 & 0,4 & 16,2 & 72,1 & 25,8 \\
\hline & \multirow[t]{3}{*}{$\begin{array}{l}\text { Patents } \\
\text {. }\end{array}$} & Patent0 & 96,6 & 98,2 & 83,8 & 85,0 & 91,9 \\
\hline & & Patent1 & 3,4 & 1,8 & 3,8 & 3,5 & 3 \\
\hline & & Patentmore1 & 0 & 0 & 12,4 & 11,5 & 5,1 \\
\hline & \multirow[t]{3}{*}{ Publications } & Publi0 & 77,2 & 44,8 & 38,1 & 60,9 & 58,9 \\
\hline & & Publi1 & 22,8 & 50,9 & 0 & 10,3 & 23,9 \\
\hline & & Publimore1 & 0 & 4,3 & 61,9 & 28,8 & 17,2 \\
\hline & \multirow[t]{3}{*}{ Dyadic } & Dya0 & 2,0 & 97,8 & 61,9 & 0 & 33,5 \\
\hline & & Dya1 & 90,3 & 1,4 & 3,8 & 7,6 & 29,7 \\
\hline & & Dyamore1 & 7,7 & 0,7 & 34,3 & 92,4 & 36,8 \\
\hline & \multirow[t]{3}{*}{ Industrial } & Indus0 & 96,3 & 40,1 & 21,0 & 87,4 & 70,3 \\
\hline & & Indus1 & 3,7 & 59,9 & 8,6 & 6,2 & 20,3 \\
\hline & & Indusmore1 & 0 & 0 & 70,5 & 6,5 & 9,4 \\
\hline & \multirow[t]{3}{*}{ University } & Univ0 & 97,3 & 54,9 & 39,0 & 80,9 & 74,3 \\
\hline & & Univ1 & 2,7 & 45,1 & 7,6 & 11,8 & 17,7 \\
\hline & & Univmore1 & 0 & 0 & 53,3 & 7,4 & 7,9 \\
\hline \multirow{17}{*}{$\begin{array}{l}\text { VARIABLES } \\
\text { OF THE } \\
\text { MULTINOMIAL } \\
\text { LOGIT }\end{array}$} & \multirow{6}{*}{ Sector of activity } & Traditional ind. & $\overline{14,1}$ & 4,0 & 5,7 & 11,8 & 9,7 \\
\hline & & Pharmacy & 21,5 & 35,0 & 36,2 & 36,5 & 31,7 \\
\hline & & IT & 14,1 & 16,6 & 21,0 & 10,6 & 14,3 \\
\hline & & Networks and services & 22,1 & 17,7 & 13,3 & 11,5 & 16,5 \\
\hline & & Chemical ind. & 17,1 & 18,4 & 16,2 & 22,9 & 19,3 \\
\hline & & Mechanical equip. & 11,1 & 8,3 & 7,6 & 6,8 & 8,5 \\
\hline & \multirow[t]{4}{*}{ Location } & France & 50 & 19,1 & 23,8 & 55,0 & 40,6 \\
\hline & & Alsace & 14,1 & 1,4 & 6,7 & 18,5 & 11,4 \\
\hline & & Internat. & 35,9 & 79,4 & 69,5 & 26,5 & 48 \\
\hline & & Indpte $<50$ & 27,5 & 18,4 & 7,6 & 17,6 & 19,7 \\
\hline & \multirow[t]{5}{*}{ Size and Status } & Subs. of large groups & 26,2 & 30,3 & 33,3 & 43,5 & 33 \\
\hline & & Subs. of small groups & 19,5 & 14,4 & 20 & 16,2 & 17,1 \\
\hline & & Indpte 50-500 & 14,8 & 14,8 & 9,5 & 8,2 & 12,1 \\
\hline & & Indpte 500-10000 & 6,7 & 11,2 & 17,1 & 6,8 & 9 \\
\hline & & Indpte $>10000$ & 5,4 & 10,8 & 12,4 & 7,6 & 8,3 \\
\hline & & Total & 298 & 277 & 105 & 340 & 1020 \\
\hline & & & $29.2 \%$ & $27.1 \%$ & $10.3 \%$ & $33.3 \%$ & $100 \%$ \\
\hline
\end{tabular}


The last class (Class 4) gathers firms which maintain regular and dyadic partnerships with the university. Class 4 , which represents $33 \%$ of ULP partners, is characterized by a strong intensity of the relations, the latter taking basically the form of research contracts (this is the case for $72 \%$ of the firms of this class). Those bilateral relations sometimes include copatenting (15\% apply for one or more patent) and co-publications (28\% made more than one publication). Moreover, additional inquiry reveals that 53\% of the firms that achieved more than one contract with the ULP collaborate with the same research lab within the ULP. Concerning the sector of activity, just like the companies of Class 2, the companies of Class 4 mainly belong to the pharmaceutical industry. They are also mainly French companies and more than average subsidiaries of a group.

Finally our results can be compared those obtained by Joly et al. (1996). We already mentionned that these authors, by analyzing the research contracts of approximately 20 labs of the INRA, identified three "logics” of collaborations between laboratories and firm. The "logic of proximity marked by interpersonal and durable relations between contractors shares some of the characteristics of relations with the partners of classe 4 in our typology (regular and dyadic collaboration pattern). The "logic of club" (achieved on the initiative of the authorities) seems to correspond to our Class 2 (where partners collaborate in a non exclusive way with the university). Lastly,we think that the "market driven logic" of Joly et alii has some common features with the collaborations undertaken by Class 1 ULP's partners (punctual and bilateral relationships).

\section{Collaboration patterns and partners' specific attributes}

The previous section highlighted that the companies which collaborate with the ULP have various profiles of interactions. They are opposed in their frequency of interactions with the university and around the exclusive character of their collaborations (bilateral vs. multilateral). To go further, we attempt to explain this diversity according to the specific attributes of firms : size and ownership status, industrial sector and geographical distance. Do they impact the frequency and the variety of the links between ULP and its private partners? For that purpose, we test membership to the different classes we obtained above using a multinomial logit estimation. The methodology is presented below. 


\subsection{The econometric model}

The multinomial logit model is seen as a generalization of the binary logit model with a polytomous and unordered dependent variable. It is a non-linear model that enables us to examine the probabilities of the $(m+1)$ different values of the dependent variable $y$. The relative choices of the partners can be defined as follows:

$$
p_{j}=\operatorname{Pr}\left(y_{i}=j\right)=\frac{\exp \left(x_{i} \beta_{j}^{*}\right)}{1+\sum_{k=1}^{m} \exp \left(x_{i} \beta_{k}^{*}\right)}
$$

with $\beta_{j}^{*}=\beta_{j}-\beta_{0}, \forall j=1,2, \ldots, m$. This formulation enables us to follow the constraint $\sum_{k=0}^{m} p_{k}=1$ and the estimated parameters must be interpreted in relation to the reference group (i.e. to value $m=0)^{10}$.

The estimation of the model is then performed by maximizing the log-likelihood function with respect to the vector of parameters $\left(\beta_{1}, \ldots, \beta_{m}\right)$. This function formulated as follows:

$$
\log (L)=\sum_{i=1}^{N} \sum_{k=1}^{m} y_{i k} x_{i} \beta_{k}-(m+1) \sum_{i=1}^{N} \log \left(1+\sum_{k=1}^{m} \exp \left(x_{i} \beta_{k}\right)\right)
$$

In our case, a firm belongs to one and only one of the four classes of the typology. Belonging to the Class 1 corresponds to the reference value of the endogenous variable. The selected explicative variables are the specific attributes of the firms. Our aim is to highlight the respective role of their geographical location, their sector of activity, their size or organization (independent vs. subsidiary of a group). The results of the multinomial logit estimation are presented in the Table 4 below.

\footnotetext{
${ }^{10}$ For a precise description of the multinomial logit model, see Thomas (2000, pp. 91-94).
} 
Table 6. The determinants of collaboration patterns of ULP partners

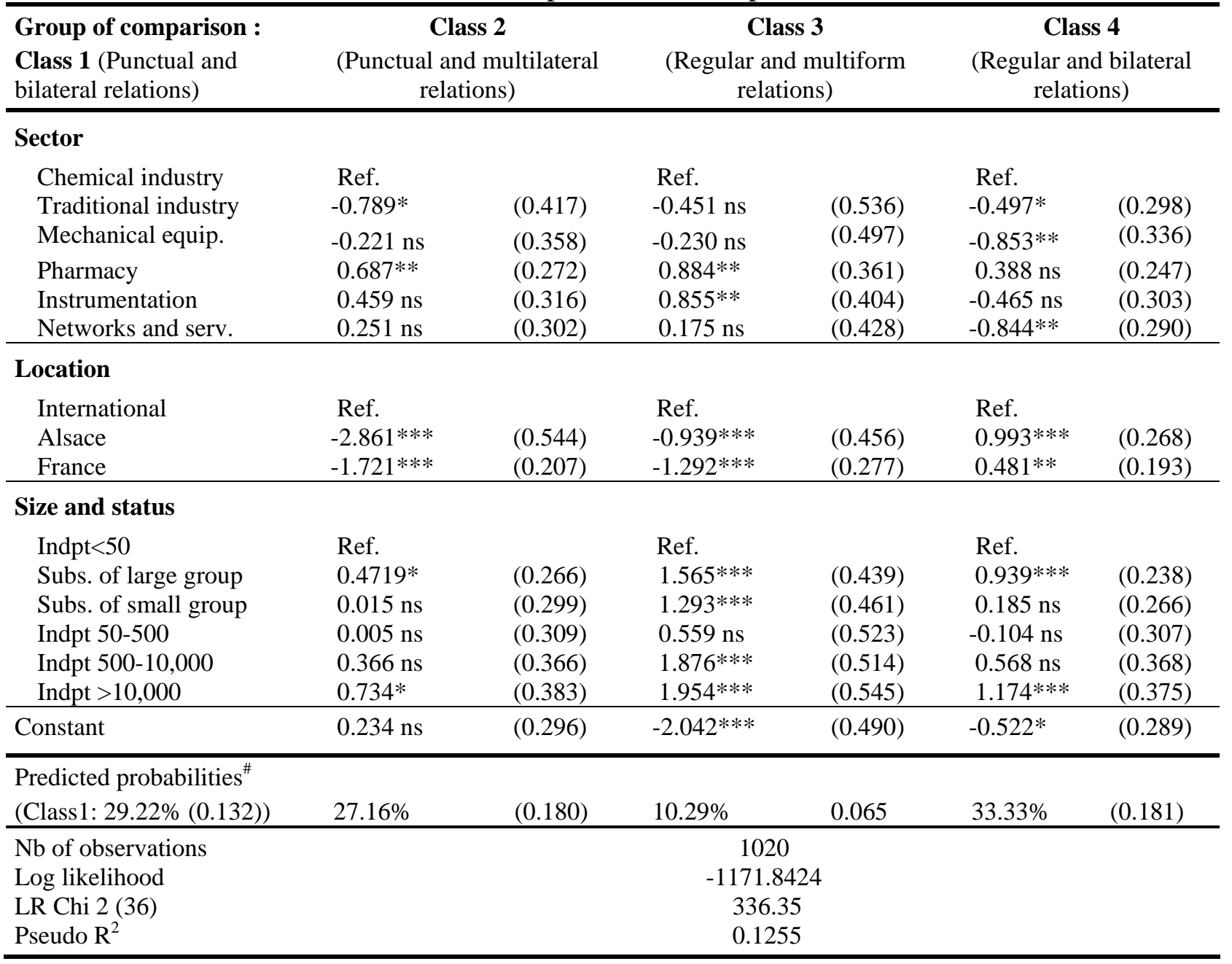

\subsection{Main results}

The sector of the private partner

The sector of the private partner clearly appears to be linked to the collaboration patterns with ULP. In particular, belonging to the pharmacy sector significantly increases the probability to engage in multilateral collaborations with ULP (i.e. to belong to classes 2 or 3). This observation can be easily explained by the fact that the firms of this sector exhibit a sciencebased mode of production according to the taxonomy of Pavitt (1984). And despite the very significant role of the protection practices through intellectual property in this sector, the pharmaceutical companies often collaborate in order to produce advanced knowledge (Hamdouch and Depret, 2001; Malerba, 2002). Indeed, according to Bureth et al. (2005a and 2005b), these firms operate according to a "coopetition mode": there is a very strong competition between the various actors of the system, but the firms of this sector have 
nevertheless to produce knowledge in collaboration with other organizations as well public as private. One can also notice that $60 \%$ of the private partners that belong to the pharmacy sector have at least one publication in collaboration with ULP (27\% of them have more than one publication). Indeed, they diffuse a share of the knowledge produced in collaboration with the university. The prevalence of this sector of activity can also be explained by the fact that this sector corresponds to the field of excellence of ULP. Indeed, in 2004, 35\% of the ULP researchers are specialized in life science.

It also seems that the firms specialized in the sectors of instrumentation and information technologies, which are also innovative sectors, have a higher chance of being privileged partners of ULP (Class 3) as well as pharmaceutical firms.

The other sectors do not constitute discriminating factors with the exception of the service firms which have a weaker probability to maintain regular and bilateral partnerships with the university (Class 4). They maintain rather bilateral partnerships (Class 1) with the university, which are to a large extent consulting firms. In fact, they are KIBS which collaborate only once and in a bilateral way with the university, the latter bringing an expertise to them on a particular problem. Moreover, these KIBS can also play the role of a mediator between universities and firms (Muller and Zenker, 2001). In this case, these companies, even if they collaborate only punctually with ULP, can favor interactions between the university with other partners of these KIBS, and thus to lead to future collaborations.

\section{The location of the private partner}

The location of the private partners also appears linked to the collaborations patterns of these firms. Thus being located in France and even more in Alsace, increases the probability of undertaking bilateral partnership with the university labs (classes 4 and 1). Here, one can presume that these regional (or national) firms need a scientific expertise on a given problem. Moreover, our result highlight that the role of proximity is even more important in the case of intense bilateral relations with ULP (Class 4). This can probably be connected to the increased role of trust when exclusive, bilateral and confidential knowledge exchanges are at stake. The "logics of proximity" in Joly et alii (1996), which is close to our class 4 collaborative pattern, highlights the importance of trust and tacit knowledge. 
An international firm has also a higher probability of being a regular partner of the university (Class 3) or to collaborate more punctually with the university in a multilateral way (Class 2). Indeed, the partners of these two classes collaborate in majority with ULP through European contracts which are obviously achieved with partners located in various European countries. We can also observe within these two classes, collaborations which combine with copublications. In this case, ULP academic researchers co-publish with industrial researchers in their field of expertise. The collaboration will be achieved, even if the firm does not belong to the regional system of innovation, nor to the national system of the university.

\section{Size and status of the private partner}

Globally, the subsidiaries of large groups or large firms are rather regular partners of the university (Class 3 and 4). Our results also stress that the independent partners with a large size (independent of more than 10,000 employees) tend to collaborate more regularly with the university than small ones. These results are in line with the studies of Adams and al (2003) and of Mohnen and Hoareau (2002) who also show that large groups have a higher propensity to collaborate with universities than small independent companies.

\section{Conclusion}

Although limited to a single European university, our analysis provides interesting insight concerning the diversity of university-industry collaborative patterns. Exploring and analysing the data concerning the contracts, co-publications and co-invented patents of the University Louis Pasteur allowed us to elaborate a typology entailing four distinct collaborative patterms, each of them presenting a strong internal coherence. More precisely, we obtain the following collaborative profiles for ULP's private partners:

- the partners who collaborate only punctually in an exclusive, bilateral way;

- the partners who collaborate punctually in an open, multilateral way;

- the partners who collaborate regularly in an open, multilateral way and through multiform relations;

- the partners who collaborate regularly in an exclusive, bilateral way.

We complemented this first important outcome of our research (the typology) by an attempt to highlight the factors behind the four classes of ULP's collaborators, using a multinomial logit model. The results show that the size, sector and proximity attributes of the companies 
contribute significantly to explain the membership to a particular classes. We can summarize the main outcomes of the model as follows:

- companies in hightech sectors (pharmaceuticals and information technologies/ instrumentation) and/or located in foreign countries have a higher propensity to activate open (multipartner) collaborations with ULP.

- domestic and regional companies have a higher propensity to activate exclusive (dyadic) and regular collaborations.

- large companies (and their subsidiaries) have a higher propensity to maintain regular, frequent collaborative relationships with ULP.

This study represents only a first step in a broader research project on university-industry relationships. To conclude we would like to mention a few limitations, which constitutes also future promising paths of investigation. First, the type of links we took into account was not complete : it would be worthwile to incorporate collaboration channels based on mobility of persons (students, scientists,...) as well. Second, organizing several interviews to collect information from the point of view of some ULP's partners would make it possible to examine whether the collaborative pattern of a given firm (for instance, activating open, multipartner and regular relationships) is specific to ULP or not. Does the firm collaborate with other universities or PROs? Does it activate the same collaborative strategy for any PRO ? Third, it would be interesting to apply the same kind of empirical analyse to other (large, scientific, and diversified) universities to evaluate the relevance of our four collaborative patterns in broader context. Finally, and most importantly, we intend to use a similar methodology to explore the diversity of collaborative links with additional information : the data concerning the research units of Univesity Louis Pasteur : personnel, performances, and so on.

\section{References}

Adams, J., 1990. “Fundamental Stocks of Knowledge and Productivity Growth”. Journal of Political Economy, 98 (4) , pp. 673-702.

Adams, J.D., Chiang, EP. et Jensen, J.L., 2003. "The influence of federal laboratory R\&D on industrial research”. Review of Economics and Statistics, 84(4), pp.1003-1020.

Arundel, A., and Geuna, A., 2004. "Proximity and the use of public science by innovative European firms”. Economics of Innovation \& New Technology, 13 (6), p559-580.

Benzécri, J.-P., 1992. Correspondence Analysis Handbook. Marcel Dekker, New York. 
Blumenthal, D., Campbell, E., Anderson, M., Causino N., and Seashore-Louis, K., 1997. "Withholding research results in academic life science: evidence from a national survey of faculty”. Journal of the Academic Medical Association, 207, pp. 1224-1228.

Bureth A., Levy R., Pénin J. et Wolff S., 2005. « Le rôle du brevet dans les biotechnologies : le cas de la BioValley du Rhin Supérieur ». A paraître dans Education et Formation.

Bureth A., Levy R., Pénin J. et Wolff S., 2006. "Patenting Practices within the Upper-Rhine Biovalley network: Coordination and Exclusion Rationales”. A paraître dans Rivista di Politica Economica.

Caloghirou, Y, Aggelos T., et Vonortas, NS., 2001. "University-Industry Cooperation in the Context of the European Framework Programmes”. Journal of Technology Transfer, 26 (1-2), pp.15361.

Cassier, M., 1997. «Compromis institutionnels et hybridations entre recherche publique et recherche privée ». Revue d'Economie Industrielle, 79, pp. 191-212.

Carayol, N., 2003. "Objectives, agreements and matching in science-industry collaborations: Reassembling the pieces of the puzzle”. Research Policy, 32, pp. 887-908.

Carayol, N et Matt M., 2004a. "The Exploitation of Complementarities in the Scientific Production Process at the Laboratory Level”. Technovation, 24 (6), pp. 455-465.

Carayol, N et Matt M., 2004b. "Does research organization influence Academic Production? Laboratory Level Evidence from a large European University”. Research Policy, 33, pp.10811102.

Cohen, W.M., Nelson R.R., \& Walsh, J.P. 2002. "Links and Impacts: The Influence of Public Research on Industrial R\&D,” Management Science, 48 (1)pp. 1-23.

Cohen, W.M., Florida, R., Randazzese, L. et Walsh, J., 1998. "Industry and the academy: uneasy partners in the cause of technological advance”. In R.G. Noll (eds), Challenges to research universities, chap. 7, pp. 171-200.

Cyert, R.M., and Goodman, P.S., 1997. "Creating Effective University-Industry Alliances: An Organizational Learning Perspective”. Organizational Dynamics, 25 (4), p45-57.

Dalpé, R., 2003. "Interaction between Public Research Organizations and Industry in Biotechnology”. Managerial and Decision Economics, 24 (2-3), pp. 171-85.

Dasgupta, P. et David, P., 1994. “Toward a new economics of science”. Research Policy, 23, pp.487521.

Estades, J., Joly, P.B. et Mangematin, V., 1996. «Dynamique des relations industrielles dans les laboratoires d'un grand organisme public de recherche : coordination apprentissage, réputation et confiance ». Sociologie du Travail, 3, pp. 391-407.

Faulkner W., \& Senker, J., 1994. "Making sense of diversity: public-private sector research linkage in three technologies”. Research Policy, 23(6), pp. 673-695. 
Fontana, R., Geuna A. and Matt M., 2006, “Factors affecting university-industry R\&D projects: The importance of searching, screening and signalling”, Forthcoming in Research Policy.

Godin, B., and Gingras, Y., 2000. "The place of universities in the system of knowledge production”. Research Policy, 29 (2), p273.

Gibbons, M. Limoges, C., Nowotny, H., Schwartzman, S., Scott, P. et Trow, M., 1994. The new production of knowledge: the dynamics of science and research in contemporary societies. Sage, London.

Hall, B., J., Link, A., N. et Scott, J.T. 2000. "Universities as research partners ». NBER Working Paper, 7643.

Hall, B.H., Link AN., and Scott, J.T., 2001. "Barriers inhibiting industry from partnering with universities: evidence from the advanced technology program”. Journal of Technology Transfer, 26, pp. 87-98.

Hamdouch, A. et Depret, MH., 2001. La nouvelle économie industrielle de la pharmacie : Structures industrielles, dynamique d'innovation et stratégies commerciales. Paris : Elsevier.

Jaffe, A.B., 1989. "Real effects of academic research”. American Economic Review, 79, pp.957-970.

Jankowski, J.E., 1999. “Trends in Academic Research Spending, Alliances, and Commercialization”. The Journal of Technology Transfer, 24 (1 ), pp. 55 - 68 .

Joly, P.B. \& Mangematin V., 1996. "Profile of public laboratories, industrial partnerships and organization of R\&D”. Research Policy, 25 (6), p901-923.

Klevorick, A.K., Levin, R., Nelson, R. et Winter, S., 1995. "On the source and significance of interindustry differences in technological opportunities”. Research Policy, 24, pp.185-205.

Laursen, K \& Salter, A., 2004. "Searching high and low: what types of firms use universities as a source of innovation?”. Research Policy, 33 (8), pp. 1201-1215.

Lee, Y.S., 1998. "University-industry collaboration on technology transfer: views from the ivory tower”. Policy Studies Journal, 26, pp.69-84.

Lee, Y.S., 2000. "The sustainability of university-industry research collaboration: an empirical assessment”. Journal of Technology Transfer, 25, pp.111-133.

Levy (2005). "La place de la recherche universitaire dans les systèmes d'innovation : une approche territorialisée”. Thèse de Doctorat de science Economiques, Université Louis Pasteur, Strasbourg.

Link, A.N., andt Scott,J.T., 2005. "Universities as partners in U.S. research joint ventures”. Research Policy, 34 (3), pp. 385-393.

Malerba, F., 2002. "Sectoral systems of innovation and production”. Research Policy, 31, pp.247-264.

Mansfield, E., 1980. "Basic Research and Productivity Increase in Manufacturing”. American Economic Review, 70(5), pp. 863-873. 
Matt, M. Wolff, S., 2004. “ Incentives, coordination and learning in government-sponsored vs. spontaneous inter-firm research cooperation”. International Journal of Technology Management, 27 ( 8), pp. 694-711.

Merton R.K., 1973. The sociology of science. In: Storer, N.W. (Ed.), Theoretical and Empirical Investigations. University Press of Chicago, Chicago.

Meyer-Krahmer, F. et Schmoch, U., 1998. "Science-based technologies: university-industry interactions in four fields”. Research Policy, 27, pp.835-851.

Miotti, L. \& Sachwald, F., 2003. “Co-operative R\&D: why and with whom?: An integrated framework of analysis”. Research Policy, 32 (8), pp. 1481-1500.

Mohnen P. et Hoareau, C., 2002. "What type of enterprise forges close links with universities and governement labs? Evidence form CIS2”. Working Paper Ciranao, 2002-25.

Muller, E. et Zenker, A., 2001. "Business services as actors of knowledge transformation and diffusion: some empirical findings on the role of KIBS in regional and national innovation systems”. Research Policy, 30, pp.1501-1516.

Pavitt, K., 1984. "Sectoral patterns of technical change: towards taxonomy and a theory". Research Policy, 13, pp. 343-373.

Salter, A.J. et Martin B.R., 2001. "The economic benefits of publicly funded basic research: a critical review”. Research Policy, 30, pp.509-532.

Schartinger, D., Rammer, C., Fischer, M.M. et Frohlich, J., 2002. "Knowledge interactions between universities and industry in Austria: sectoral patterns and determinants”. Research Policy, 31, pp. 303-328.

Tether, BS., 2002. "Who co-operates for innovation, and why. An empirical analysis". Research Policy, 31, pp.947-967.

Thomas A., 2000. Econométrie des variables qualitatives, Dunod, Paris. 


\section{Documents de travail du BETA}

2000-01 Hétérogénéité de travailleurs, dualisme et salaire d'efficience. Francesco DE PALMA, janvier 2000.

2000-02 An Algebraic Index Theorem for Non-smooth Economies. Gaël GIRAUD, janvier 2000.

2000-03 Wage Indexation, Central Bank Independence and the Cost of Disinflation. Giuseppe DIANA, janvier 2000.

2000-04 Une analyse cognitive du concept de « vision entrepreneuriale ». Frédéric CRÉPLET, Babak MEHMANPAZIR, février 2000.

2000-05 Common knowledge and consensus with noisy communication. Frédéric K৫SSLER, mars 2000.

2000-06 Sunspots and Incomplete Markets with Real Assets. Nadjette LAGUÉCIR, avril 2000.

2000-07 Common Knowledge and Interactive Behaviors : A Survey. Frédéric KCESSLER, mai 2000.

2000-08 Knowledge and Expertise : Toward a Cognitive and Organisational Duality of the Firm. Frédéric CRÉPLET, Olivier DUPOUËT, Francis KERN, Francis MUNIER, mai 2000.

2000-09 Tie-breaking Rules and Informational Cascades : A Note. Frédéric KESSLER, Anthony ZIEGELMEYER, juin 2000.

2000-10 SPQR : the Four Approaches to Origin-Destination Matrix Estimation for Consideration by the MYSTIC Research Consortium.

Marc GAUDRY, juillet 2000.

2000-11 SNUS-2.5, a Multimoment Analysis of Road Demand, Accidents and their Severity in Germany, 1968-1989.

Ulrich BLUM, Marc GAUDRY, juillet 2000.

2000-12 On the Inconsistency of the Ordinary Least Squares Estimator for Spatial Autoregressive Processes.

Théophile AZOMAHOU, Agénor LAHATTE, septembre 2000.

2000-13 Turning Box-Cox including Quadratic Forms in Regression. Marc GAUDRY, Ulrich BLUM, Tran LIEM, septembre 2000.

2000-14 Pour une approche dialogique du rôle de l'entrepreneur/managerdans l'évolution des PME : I'ISO comme révélateur ...

Frédéric CRÉPLET, Blandine LANOUX, septembre 2000.

2000-15 Diversity of innovative strategy as a source of technological performance.

Patrick LLERENA, Vanessa OLTRA, octobre 2000.

2000-16 Can we consider the policy instruments as cyclical substitutes ?

Sylvie DUCHASSAING, Laurent GAGNOL, décembre 2000. 
2001-01 Economic growth and CO2 emissions : a nonparametric approach.

Théophile AZOMAHOU, Phu NGUYEN VAN, janvier 2001.

2001-02 Distributions supporting the first-order approach to principal-agent problems.

Sandrine SPÆETER, février 2001.

2001-03 Développement durable et Rapports Nord-Sud dans un Modèle à Générations Imbriquées : interroger le futur pour éclairer le présent.

Alban VERCHÈRE, février 2001.

2001-04 Modeling Behavioral Heterogeneity in Demand Theory.

Isabelle MARET, mars 2001.

2001-05 Efficient estimation of spatial autoregressive models.

Théophile AZOMAHOU, mars 2001.

2001-06 Un modèle de stratégie individuelle de primo-insertion professionnelle.

Guy TCHIBOZO, mars 2001.

2001-07 Endogenous Fluctuations and Public Services in a Simple OLG Economy. Thomas SEEGMULLER, avril 2001.

2001-08 Behavioral Heterogeneity in Large Economies.

Gaël GIRAUD, Isabelle MARET, avril 2001.

2001-09 GMM Estimation of Lattice Models Using Panel Data : Application. Théophile AZOMAHOU, avril 2001.

2001-10 Dépendance spatiale sur données de panel : application à la relation Brevets-R\&D au niveau régional.

Jalal EL OUARDIGHI, avril 2001.

2001-11 Impact économique régional d'un pôle universitaire : application au cas strasbourgeois.

Laurent GAGNOL, Jean-Alain HÉRAUD, mai 2001.

2001-12 Diversity of innovative strategy as a source of technological performance.

Patrick LLERENA, Vanessa OLTRA, mai 2001.

2001-13 La capacité d'innovation dans les regions de l'Union Européenne.

Jalal EL OUARDIGHI, juin 2001.

2001-14 Persuasion Games with Higher Order Uncertainty.

Frédéric K৫SSLER, juin 2001.

2001-15 Analyse empirique des fonctions de production de Bosnie-Herzégovine sur la période 1952-1989.

Rabija SOMUN, juillet 2001.

2001-16 The Performance of German Firms in the Business-Related Service Sectors : a Dynamic Analysis.

Phu NGUYEN VAN, Ulrich KAISER, François LAISNEY, juillet 2001.

2001-17 Why Central Bank Independence is high and Wage indexation is low.

Giuseppe DIANA, septembre 2001.

2001-18 Le mélange des ethnies dans les PME camerounaises: l'émergence d'un modèle d'organisation du travail.

Raphaël NKAKLEU, octobre 2001. 
2001-19 Les déterminants de la GRH des PME camerounaises.

Raphaël NK AKLEU, octobre 2001.

2001-20 Profils d'identité des dirigeants et stratégies de financement dans les PME camerounaises. Raphaël NKAKLEU, octobre 2001.

2001-21 Concurrence Imparfaite, Variabilité du Taux de Marge et Fluctuations Endogènes.

Thomas SEEGMULLER, novembre 2001.

2001-22 Determinants of Environmental and Economic Performance of Firms : An Empirical Analysis of the European Paper Industry.

Théophile AZOMAHOU, Phu NGUYEN VAN et Marcus WAGNER, novembre 2001.

2001-23 The policy mix in a monetary union under alternative policy institutions and asymmetries. Laurent GAGNOL et Moïse SIDIROPOULOS, décembre 2001.

2001-24 Restrictions on the Autoregressive Parameters of Share Systems with Spatial Dependence. Agénor LAHATTE, décembre 2001.

2002-01 Strategic Knowledge Sharing in Bayesian Games : A General Model. Frédéric KESSLER, janvier 2002.

2002-02 Strategic Knowledge Sharing in Bayesian Games : Applications.

Frédéric KESSLER, janvier 2002.

2002-03 Partial Certifiability and Information Precision in a Cournot Game. Frédéric KESSLER, janvier 2002.

2002-04 Behavioral Heterogeneity in Large Economies.

Gaël GIRAUD, Isabelle MARET, janvier 2002.

(Version remaniée du Document de Travail n²001-08, avril 2001).

2002-05 Modeling Behavioral Heterogeneity in Demand Theory.

Isabelle MARET, janvier 2002.

(Version remaniée du Document de Travail n²001-04, mars 2001).

2002-06 Déforestation, croissance économique et population : une étude sur données de panel. Phu NGUYEN VAN, Théophile AZOMAHOU, janvier 2002.

2002-07 Theories of behavior in principal-agent relationships with hidden action.

Claudia KESER, Marc WILLINGER, janvier 2002.

2002-08 Principe de précaution et comportements préventifs des firmes face aux risques environnementaux.

Sandrine SPÆTER, janvier 2002.

2002-09 Endogenous Population and Environmental Quality.

Phu NGUYEN VAN, janvier 2002.

2002-10 Dualité cognitive et organisationnelle de la firme au travers du concept de communauté. Frédéric CRÉPLET, Olivier DUPOUËT, Francis KERN, Francis MUNIER, février 2002.

2002-11 Comment évaluer l'amélioration du bien-être individuel issue d'une modification de la qualité du service d'élimination des déchets ménagers?

Valentine HEINTZ, février 2002. 
2002-12 The Favorite-Longshot Bias in Sequential Parimutuel Betting with Non-Expected Utility Players.

Frédéric K৫SSLER, Anthony ZIEGELMEYER, Marie-Hélène BROIHANNE, février 2002.

2002-13 La sensibilité aux conditions initiales dans les processus individuels de primo-insertion professionnelle : critère et enjeux.

Guy TCHIBOZO, février 2002.

2002-14 Improving the Prevention of Environmental Risks with Convertible Bonds.

André SCHMITT, Sandrine SPAETER, mai 2002.

2002-15 L'altruisme intergénérationnel comme fondement commun de la courbe environnementale à la Kuznets et du développement durable.

Alban VERCHÈRE, mai 2002.

2002-16 Aléa moral et politiques d'audit optimales dans le cadre de la pollution d'origine agricole de l'eau.

Sandrine SPÆETER, Alban VERCHÈRE, juin 2002.

2002-17 Parimutuel Betting under Asymmetric Information.

Frédéric KESSLER, Anthony ZIEGELMEYER, juin 2002.

2002-18 Pollution as a source of endogenous fluctuations and periodic welfare inequality in OLG economies.

Thomas SEEGMULLER, Alban VERCHÈRE, juin 2002.

2002-19 La demande de grosses coupures et l'économie souterraine.

Gilbert KENIG, juillet 2002.

2002-20 Efficiency of Nonpoint Source Pollution Instruments with Externality Among Polluters : An Experimental Study.

François COCHARD, Marc WILLINGER, Anastasios XEPAPADEAS, juillet 2002.

2002-21 Taille optimale dans l'industrie du séchage du bois et avantage compétitif du bois-énergie : une modélisation microéconomique.

Alexandre SOKIC, octobre 2002.

2002-22 Modelling Behavioral Heterogeneity.

Gaël GIRAUD, Isabelle MARET, novembre 2002.

2002-23 Le changement organisationnel en PME : quels acteurs pour quels apprentissages ?

Blandine LANOUX, novembre 2002.

2002-24 TECHNOLOGY POLICY AND COOPERATION : An analytical framework for a paradigmatic approach.

Patrick LLERENA, Mireille MATT, novembre 2002.

2003-01 Peut-on parler de délégation dans les PME camerounaises ?

Raphaël NKAKLEU, mars 2003.

2003-02 L'identité organisationnelle et création du capital social: la tontine d'entreprise comme facteur déclenchant dans le contexte africain.

Raphaël NKAKLEU, avril 2003.

2003-03 A semiparametric analysis of determinants of protected area.

Phu NGUYEN VAN, avril 2003. 
2003-04 Strategic Market Games with a Finite Horizon and Incomplete Markets.

Gaël GIRAUD et Sonia WEYERS, avril 2003.

2003-05 Exact Homothetic or Cobb-Douglas Behavior Through Aggregation.

Gaël GIRAUD et John K.-H. QUAH, juin 2003.

2003-06 Relativité de la satisfaction dans la vie : une étude sur données de panel.

Théophile AZOMAHOU, Phu NGUYEN VAN, Thi Kim Cuong PHAM, juin 2003.

2003-07 A model of the anchoring effect in dichotomous choice valuation with follow-up. Sandra LECHNER, Anne ROZAN, François LAISNEY, juillet 2003.

2003-08 Central Bank Independence, Speed of Disinflation and the Sacrifice Ratio. Giuseppe DIANA, Moïse SIDIROPOULOS, juillet 2003.

2003-09 Patents versus ex-post rewards : a new look.

Julien PÉNIN, juillet 2003.

2003-10 Endogenous Spillovers under Cournot Rivalry and Co-opetitive Behaviors. Isabelle MARET, août 2003.

2003-11 Les propriétés incitatives de l'effet Saint Matthieu dans la compétition académique.

Nicolas CARAYOL, septembre 2003.

2003-12 The 'probleme of problem choice': A model of sequential knowledge production within scientific communities.

Nicolas CARAYOL, Jean-Michel DALLE, septembre 2003.

2003-13 Distribution Dynamics of $\mathrm{CO}_{2}$ Emissions.

Phu NGUYEN VAN, décembre 2003.

2004-01 Utilité relative, politique publique et croissance économique.

Thi Kim Cuong PHAM, janvier 2004.

2004-02 Le management des grands projets de haute technologie vu au travers de la coordination des compétences.

Christophe BELLEVAL, janvier 2004.

2004-03 Pour une approche dialogique du rôle de l'entrepreneur/manager dans l'évolution des PME : I'ISO comme révélateur ...

Frédéric CRÉPLET, Blandine LANOUX, février 2004.

2004-04 Consistent Collusion-Proofness and Correlation in Exchange Economies.

Gaël GIRAUD, Céline ROCHON, février 2004.

2004-05 Generic Efficiency and Collusion-Proofness in Exchange Economies.

Gaël GIRAUD, Céline ROCHON, février 2004.

2004-06 Dualité cognitive et organisationnelle de la firme fondée sur les interactions entre les communautés épistémiques et les communautés de pratique..

Frédéric CRÉPLET, Olivier DUPOUËT, Francis KERN, Francis MUNIER, février 2004.

2004-07 Les Portails d'entreprise: une réponse aux dimensions de l'entreprise «processeur de connaissances ».

Frédéric CRÉPLET, février 2004. 
2004-08 Cumulative Causation and Evolutionary Micro-Founded Technical Change: A Growth Model with Integrated Economies.

Patrick LLERENA, André LORENTZ, février 2004.

2004-09 Les CIFRE : un outil de médiation entre les laboratoires de recherche universitaire et les entreprises.

Rachel LÉVY, avril 2004.

2004-10 On Taxation Pass-Through for a Monopoly Firm.

Rabah AMIR, Isabelle MARET, Michael TROGE, mai 2004.

2004-11 Wealth distribution, endogenous fiscal policy and growth : status-seeking implications.

Thi Kim Cuong PHAM, juin 2004.

2004-12 Semiparametric Analysis of the Regional Convergence Process.

Théophile AZOMAHOU, Jalal EL OUARDIGHI, Phu NGUYEN VAN, Thi Kim Cuong PHAM, Juillet 2004.

2004-13 Les hypothèses de rationalité de l'économie évolutionniste. Morad DIANI, septembre 2004.

2004-14 Insurance and Financial Hedging of Oil Pollution Risks.

André SCHMITT, Sandrine SPAETER, septembre 2004.

2004-15 Altruisme intergénérationnel, développement durable et équité intergénérationnelle en présence d'agents hétérogènes.

Alban VERCHĖRE, octobre 2004.

2004-16 Du paradoxe libéral-parétien à un concept de métaclassement des préférences.

Herrade IGERSHEIM, novembre 2004.

2004-17 Why do Academic Scientists Engage in Interdisciplinary Research ?

Nicolas CARAYOL, Thuc Uyen NGUYEN THI, décembre 2004.

2005-01 Les collaborations Université Entreprises dans une perspective organisationnelle et cognitive.

Frédéric CRÉPLET, Francis KERN, Véronique SCHAEFFER, janvier 2005.

2005-02 The Exact Insensitivity of Market Budget Shares and the 'Balancing Effect'.

Gaël GIRAUD, Isabelle MARET, janvier 2005.

2005-03 Les modèles de type Mundell-Fleming revisités.

Gilbert KOENIG, janvier 2005.

2005-04 L'État et la cellule familiale sont-ils substituables dans la prise en charge du chômage en Europe ? Une comparaison basée sur le panel européen.

Olivia ECKERT-JAFFE, Isabelle TERRAZ, mars 2005.

2005-05 Environment in an Overlapping Generations Economy with Endogenous Labor Supply : a Dynamic Analysis.

Thomas SEEGMULLER, Alban VERCHÈRE, mars 2005.

2005-06 Is Monetary Union Necessarily Counterproductive?

Giuseppe DIANA, Blandine ZIMMER, mars 2005.

2005-07 Factors Affecting University-Industry R\&D Collaboration : The importance of screening and signalling.

Roberto FONTANA, Aldo GEUNA, Mireille MATT, avril 2005. 
2005-08 Madison-Strasbourg, une analyse comparative de l'enseignement supérieur et de la recherche en France et aux États-Unis à travers l'exemple de deux campus.

Laurent BUISSON, mai 2005.

2005-09 Coordination des négociations salariales en UEM : un rôle majeur pour la BCE.

Blandine ZIMMER, mai 2005.

2005-10 Open knowledge disclosure, incomplete information and collective innovations.

Julien PÉNIN, mai 2005.

2005-11 Science-Technology-Industry Links and the 'European Paradox': Some Notes on the Dynamics of Scientific and Technological Research in Europe.

Giovanni DOSI, Patrick LLERENA, Mauro SYLOS LABINI, juillet 2005.

2005-12 Hedging Strategies and the Financing of the 1992 International Oil Pollution Compensation Fund.

André SCHMITT, Sandrine SPAETER, novembre 2005.

2005-13 Faire émerger la coopération internationale: une approche expérimentale comparée du bilatéralisme et du multilatéralisme.

Stéphane BERTRAND, Kene BOUN MY, Alban VERCHÈRE, novembre 2005.

2005-14 Segregation in Networks.

Giorgio FAGIOLO, Marco VALENTE, Nicolaas J. VRIEND, décembre 2005.

2006-01 Demand and Technology Determinants of Structural Change and Tertiarisation : An InputOutput Structural Decomposition Analysis for four OECD Countries.

Maria SAVONA, André LORENTZ, janvier 2006.

2006-02 A strategic model of complex networks formation.

Nicolas CARAYOL, Pascale ROUX, janvier 2006.

2006-03 Coordination failures in network formation.

Nicolas CARAYOL, Pascale ROUX, Murat YILDIZOGLU, janvier 2006.

2006-04 Real Options Theory for Lawmaking.

Marie OBIDZINSKI, Bruno DEFFAINS, août 2006.

2006-05 Ressources, compétences et stratégie de la firme : Une discussion de l'opposition entre la vision Porterienne et la vision fondée sur les compétences.

Fernand AMESSE, Arman AVADIKYAN, Patrick COHENDET, janvier 2006.

2006-06 Knowledge Integration and Network Formation.

Müge OZMAN, janvier 2006.

2006-07 Networks and Innovation : A Survey of Empirical Literature.

Müge OZMAN, février 2006.

2006-08 A.K. Sen et J.E. Roemer : une même approche de la responsabilité ? Herrade IGERSHEIM, mars 2006.

2006-09 Efficiency and coordination of fiscal policy in open economies.

Gilbert KOENIG, Irem ZEYNELOGLU, avril 2006.

2006-10 Partial Likelihood Estimation of a Cox Model With Random Effects : an EM Algorithm Based on Penalized Likelihood.

Guillaume HORNY, avril 2006. 
2006-11 Uncertainty of Law and the Legal Process.

Giuseppe DARI-MATTIACCI, Bruno DEFFAINS, avril 2006.

2006-12 Customary versus Technological Advancement Tests.

Bruno DEFFAINS, Dominique DEMOUGIN, avril 2006.

2006-13 Institutional Competition, Political Process and Holdup.

Bruno DEFFAINS, Dominique DEMOUGIN, avril 2006.

2006-14 How does leadership support the activity of communities of practice ?

Paul MULLER, avril 2006.

2006-15 Do academic laboratories correspond to scientific communities ? Evidence from a large European university.

Rachel LÉVY, Paul MULLER, mai 2006.

2006-16 Knowledge flows and the geography of networks. A strategic model of small worlds formation.

Nicolas CARAYOL, Pascale ROUX, mai 2006.

2006-17 A Further Look into the Demography-based GDP Forecasting Method. Tapas K. MISHRA, juin 2006.

2006-18 A regional typology of innovation capacities in new member states and candidate countries. Emmanuel MULLER, Arlette JAPPE, Jean-Alain HÉRAUD, Andrea ZENKER, juillet 2006.

2006-19 Convergence des contributions aux inégalités de richesse dans le développement des pays européens.

Jalal EL OUARDIGHI, Rabiji SOMUN-KAPETANOVIC, septembre 2006.

2006-20 Channel Performance and Incentives for Retail Cost Misrepresentation.

Rabah AMIR, Thierry LEIBER, Isabelle MARET, septembre 2006.

2006-21 Entrepreneurship in biotechnology: The case of four start-ups in the Upper-Rhine Biovalley.

Antoine BURETH, Julien PÉNIN, Sandrine WOLFF, septembre 2006.

2006-22 Does Model Uncertainty Lead to Less Central Bank Transparency?

Li QIN, Elefterios SPYROMITROS, Moïse SIDIROPOULOS, octobre 2006.

2006-23 Enveloppe Soleau et droit de possession antérieure : Définition et analyse économique. Julien PÉNIN, octobre 2006.

2006-24 Le territoire français en tant que Système Régional d'Innovation.

Rachel LEVY, Raymond WOESSNER, octobre 2006.

2006-25 Fiscal Policy in a Monetary Union Under Alternative Labour-Market Structures. Moïse SIDIROPOULOS, Eleftherios SPYROMITROS, octobre 2006.

2006-26 Robust Control and Monetary Policy Delegation.

Giuseppe DIANA, Moïse SIDIROPOULOS, octobre 2006. 
2006-27 A study of science-industry collaborative patterns in a large european university. Rachel LEVY, Pascale ROUX, Sandrine WOLFF, octobre 2006.

La présente liste ne comprend que les Documents de Travail publiés à partir du $1^{\mathrm{er}}$ janvier 2000. La liste complète peut être donnée sur demande.

This list contains the Working Paper writen after January 2000, 1rst. The complet list is available upon request. 